\title{
Occurrence and Antibiotic Susceptibility Profile of Streptococcus spp. Isolated from Ewe's Milk
}

\author{
Athanasios Alexopoulos ${ }^{1}$, Stavros Plessas ${ }^{1}$, Zafiris Abas ${ }^{1}$, Vasiliki Lagka ${ }^{2}$, Antonis Zdragas ${ }^{3}$ and Eugenia \\ Bezirtzoglou ${ }^{1}$ \\ 1. Faculty of Agricultural Development, Laboratory of Microbiology, Biotechnology \& Hygiene, Democritus University of Thrace, \\ Orestiada GR68200, Greece
}

2. Department of Animal Production, School of Agricultural Technology, Alexander Technological Educational Institute of Thessaloniki (ATEITH), Thessaloniki GR57400, Greece

3. National Agricultural Research Foundation (NAGREF), Veterinary Research Institute of Thessaloniki, NAGREF Campus of Thermi, GR57001, Greece

Received: October 21, 2013 / Published: December 20, 2013.

\begin{abstract}
The purpose of this study was to determine the occurrence and antimicrobial resistance of Streptococcus spp. isolated from fresh ewe's milk and consequently to draw conclusions concerning the health condition of the animal flocks and the current trends of antibiotic use in small ruminants. A total of 77 mountainous sheepfolds were investigated representing $10 \%$ of all transhumant sheep and goats flocks in the area. Duplicate milk samples were collected from January to February transferred to the laboratory and analyzed for the presence of Streptococcus spp. by using the serial dilution method and plating on the surface of Slanetz and Bartley agar. The isolates were tested against nine antimicrobial agents with the Kirby-Bauer disk diffusion method. The results showed that Streptococcus spp. occurred in $84.4 \%$ of the samples and in counts ranged between $1.8 \log$ CFU/mL and 4.6 log CFU/mL. Concerning susceptibility, only $1.3 \%$ of the isolates were resistant to all antimicrobials while $27.3 \%$ were fully susceptible. Resistance to cefepime was the most common (93.1\%) observation followed by resistance to ampicillin (82.1\%), ciprofloxacine (58.3\%) and meropenem $(51.9 \%)$. The isolates were vancomycin susceptible at a rate of $83.6 \%$. Multidrug resistance to at least three antibiotics was observed to be $22.1 \%$ of Streptococcus spp.. Given the prevalence of Streptococcus spp. and the elevated resistance of isolates to various antibiotics it is concluded that further examinations and even interventions are required in order to pertain the appropriate animal health and milk quality.
\end{abstract}

Key words: Antibiotic, ewe's milk, Streptococcus.

\section{Introduction}

Ewe farming is an important branch of the national economy for many Mediterranean countries supporting the meat and dairy industry [1]. In Greece, ewe's and goat's milk is the key material for production of Greek yogurt, feta and other protected designation of origin (PDO) cheeses. Milk production in Greece has been estimated to be about $680,000 \mathrm{t} /$ year, which is the second larger production among the European

\footnotetext{
Corresponding author: Eugenia Bezirtzoglou, professor, research field: food microbiology. E-mail: empezirt@agro.duth.gr.
}

countries [2].

Among the various factors which affect the milk quality [3], mastitis caused by bacteria resistant to various antimicrobial agents is undoubtedly the major one [4]. Mastitis in ewes, goat or bovines can be caused by many different bacterial species, the most common of which are Staphylococcus and Streptococcus genera [5]. Due to the variety of antimicrobials in use used for the prevention and treatment, an inevitable resistance to antibiotics is expected $[6,7]$. As a result, various effects anticipated for the livestock health and production $[8,9]$ or for the public $[10,11]$ 
accompanied by an increased economic cost [12].

Streptococcal species are major mastitis pathogens along with Staphylococcus aureus and coliforms. Some of the Streptococcus spp., as for example Streptococcus agalactiae in cows are animal associated and well adapted to their mammary glands whereas others (S. disgalactiae, S. uberis, S. bovis, S. oralis, etc.) are environmental strains acting as opportunistic pathogens [13]. However, various studies have shown that such environmental streptococci are becoming increasingly resistant to many antimicrobial agents and are known to be reservoirs of resistant genes, transferring different resistant traits to more pathogenic organisms $[14,15]$.

Although several studies have been conducted on the antimicrobial resistance of streptococci [16-18], only limited data are available on multidrug resistance of various Streptococcus species from ewe's milk. The aim of this study was to study the occurrence of gram-positive bacteria belonging to the Streptococcus genus and to determine their resistance to various antibiotics.

\section{Materials and Methods}

\subsection{Microbiological Determinations}

A total of $10 \%$ of transhumant sheep and goats flocks, representing approximately 20,000 milked ewes, were investigated. Milk samples were collected from refrigerated tanks during the period of January and February 2012 just before the milk carried to the milk plant. Samples were collected from farms located in mountainous areas in Central Greece. Milking of the flock was supervised by team members. After a visual inspection of each animal, the udder exterior was washed and carefully dried with a clean towel and the teats swabbed with $70 \%$ alcohol. Duplicate milk samples were placed in an ice container and transferred to the laboratory for bacteriological examination.

\subsection{Bacteriological Examination}

The collected milk samples were placed in a water bath at $36{ }^{\circ} \mathrm{C}$ for $30 \mathrm{~min}$ and afterwards they serially diluted in tubes containing sterile saline $(0.9 \% \mathrm{NaCl})$. Aliquots of $100 \mu \mathrm{L}$ were plated onto Petri dishes with Slanetz \& Bartley agar and incubated initially at $36^{\circ} \mathrm{C}$. Four hours later the incubation temperature was raised to $44{ }^{\circ} \mathrm{C}$ and remained there for $48 \mathrm{~h}$ as an additional step towards selection of streptococci. The isolates were identified by their characteristic morphology as showed in Gram stain, catalase-negative reaction and esculin hydrolysis. Plates with isolates in a range of 25-250 were used for enumeration (CFU/mL of milk).

\subsection{Antibiotic Sensitivity Testing}

Antimicrobial resistance of Streptococcus spp. was tested using the disk diffusion method. Three to five isolates from each plate were harvested and diluted in sterile saline at a concentration of 0.5 turbitity units of the McFarland scale to obtain an inoculum with approximately $1.5 \times 10^{8} \mathrm{CFU} / \mathrm{mL}$. The surface of agar plates contained cation-adjusted Muller-Hinton was inoculated with a sterile swap and the antibiotic disks were placed after $15 \mathrm{~min}$. Subsequently, the plates were incubated aerobically for $16 \mathrm{~h}$ to $20 \mathrm{~h}$ at $35^{\circ} \mathrm{C}$ and then the diameter of the inhibition zone was measured. The following disks with antibiotics were used: amoxicillin (25 $\mu \mathrm{g})$, ampicillin $(10 \mu \mathrm{g})$, cefepime $(30 \mu \mathrm{g})$, ciprofloxacin $(5 \mu \mathrm{g})$, levofloxacin $(5 \mu \mathrm{g})$, meropenem (10 $\mu \mathrm{g})$, piperacillin $(100 \mu \mathrm{g})$, piperacillin/tazobactam $(100 / 10 \mu \mathrm{g})$ and vancomycin $(10 \mu \mathrm{g})$.

The breakpoints used were those published by the European Committee on Antimicrobial Susceptibility Testing (EUCAST, 2012) for Streptococcus and/or Enterococcus spp.. Multidrug resistance was defined as resistance to three or more agents [19].

\subsection{Statistical Analysis}

Distribution of Streptococcus spp. isolates and antibiotic resistance are presented by frequency and percentages. Computational values are based on logarithmically transformed counts. Comparison of occurrence and susceptibility rates was performed by 
using Fisher's exact chi-squared test. Significant levels were defined at $P<0.05$.

\section{Results and Discussion}

During this study, 77 ewe's milk samples were examined for the presence of various Streptococcus spp.. Of all samples, $12(15.6 \%)$ were negative regarding this genus and $65(84.4 \%)$ were positive (Table 1). Counts in positive samples were ranged between $70 \mathrm{CFU} / \mathrm{mL}(1.8 \log \mathrm{CFU} / \mathrm{mL})$ and 40,000 $\mathrm{CFU} / \mathrm{mL}$ (4.6 $\log \mathrm{CFU} / \mathrm{mL}$ ). In general an average of $2.67 \pm 1.3 \log \mathrm{CFU} / \mathrm{mL}$ was recorded. These counts are consistent with those published by Kondyli et al. [3] who reported that the mean values of Enterococcus and Streptococcus combined in ewe's milk was between $3.13 \log \mathrm{CFU} / \mathrm{mL}$ and $3.80 \log \mathrm{CFU} / \mathrm{mL}$. On the contrary, other investigators from European countries and elsewhere reported lower incidence patterns. El-Jakee et al. [20] reported a $50.4 \%$ of positive samples in Egypt among 270 tested ewe farms. Marogna et al. [4] reported that streptococci were the second most common finding in milk samples from Sardinia with Streprococcus spp. and Enterococcus spp. in combination isolated from $16.6 \%$ of the samples. In a similar study from Spain, both groups represented the $6 \%$ of all isolates [21] while the corresponding number from Scotland was 2.8\% [22]. Streptococcus bovis, S. suis and S. uberis were isolated from six out of 354 ewe's milk samples examined from Arsenault et al. [23] in Quebec, Canada. The distribution of streptococci in another study from Italy ranged from $9.6 \%$ to $10.9 \%$ [24]. These findings suggest that a relatively low microbiological quality of raw ewe's milk is recorded in the study. Based on the literature this could be related to factors such as area, animal breed, stage of lactation, hygienic conditions of milk production and handling [24-27].

In this study, streptococci were tested for resistance to nine antibiotics belonging to six different classes. Table 2 presents the percentages of antibiotic resistant patterns for the isolates during this study. The most effective antimicrobial agents were vancomycine and levofloxacine with a resistance of $9.1 \%$ and $1.2 \%$, respectively. Amoxicillin and piperacillin from penicillins were effective enough (resistant at 19.2\% and $14.8 \%$ ) while ampicillin, cefepime, meropenem and ciprofloxacine were the least effective with a resistance rate of $82.1 \%, 93.1 \%$ and $58.3 \%$, respectively. The data for streptococci resistance to antimicrobials in sheep's milk are not as extensive as for other pathogens, and for comparison data from cow's milk have often been used. Ebrahimi et al. [28] identified that streptococci isolated from cows showed high resistance to amoxicillin (76.9\%) and ampicillin $(61.5 \%-88.8 \%)$. The strains in the study were susceptible to piperacillin (48.1\%) and amoxicillin (63.5\%) but resistant to ampicillin (82.1\%). In a retrospective study of Lollai et al. [29], Streptococcus isolates showed rates of resistance to ampicillin (up to $12.2 \%$ ) comparable to those reported for the genus of cattle farms. El-Jakee et al. [20] reported a 20\% and 60\%

Table 1 Occurrence of Streptococcus spp. isolated from ewe's milk $(n=77)$.

\begin{tabular}{llll}
\hline $\begin{array}{l}\text { Counts } \\
(\mathrm{CFU} / \mathrm{mL})\end{array}$ & $\begin{array}{l}\text { Counts } \\
(\log 10 \mathrm{CFU} / \mathrm{mL})\end{array}$ & $\begin{array}{l}\text { Number } \\
\text { of samples }\end{array}$ & $\begin{array}{l}\text { Percentage } \\
\text { of samples }\end{array}$ \\
\hline Non detected & & 12 & 15.6 \\
$1-100$ & $0-2$ & 6 & 7.8 \\
$101-500$ & $2-2.7$ & 13 & 16.9 \\
$501-1,000$ & $2.7-3$ & 7 & 9.0 \\
$1,001-5,000$ & $3-3.7$ & 23 & 29.9 \\
$5,001-10,000$ & $3.7-4$ & 12 & 15.6 \\
$>10,000$ & $>4$ & 4 & 5.2 \\
\hline Total & & 77 & 100 \\
\hline
\end{tabular}

Table 2 Percentages of antibiotic resistance patterns of Streptococcus spp. isolated from ewe's milk.

\begin{tabular}{|c|c|c|c|}
\hline Class & Antibiotic & $\mathrm{R} \% \mathrm{I} \%$ & $\mathrm{~S} \%$ \\
\hline \multirow{3}{*}{ Penicillins } & Amoxicillin & 19.217 .3 & 63.5 \\
\hline & Ampicillin & 82.110 .7 & 7.1 \\
\hline & Piperacillin & 14.837 .0 & 48.1 \\
\hline $\begin{array}{l}\beta \text {-lactam/ } \beta \text {-lactamase } \\
\text { inhibitors }\end{array}$ & Piperacillin/tazobactam & 35.242 .6 & 22.2 \\
\hline Cephalosporin IV & Cefepime & 93.10 .0 & 6.9 \\
\hline Carbapenem & Meropenem & 51.90 .0 & 48.1 \\
\hline \multirow{2}{*}{ Fluoroquinolones } & Ciprofloxacine & 58.320 .8 & 20.8 \\
\hline & Levofloxacine & $1.8 \quad 0.0$ & 98.2 \\
\hline Glycopeptides & Vancomycin & 9.17 .3 & 83.6 \\
\hline
\end{tabular}


Table 3 Frequency of multidrug resistance of Streptococcus spp. isolated from ewe's milk.

\begin{tabular}{llll}
\hline $\begin{array}{l}\text { Number of } \\
\text { antibiotics }\end{array}$ & Frequency & $\%$ & Cumulative \% \\
\hline 0 & 21 & 27.3 & \\
1 & 12 & 15.6 & 15.6 \\
2 & 18 & 23.4 & 38.9 \\
3 & 9 & 11.7 & 50.6 \\
4 & 10 & 13.0 & 63.6 \\
5 & 5 & 6.5 & 70.1 \\
6 & 1 & 1.3 & 71.4 \\
7 & 1 & 1.3 & 72.7 \\
\hline Total & 77 & 100.0 & \\
\hline
\end{tabular}

of resistance to ampicillin and vancomycin, respectively, from Egypt. Moatamedi et al. [30] revealed susceptibility of streptococci to amoxicillin and ciprofloxacine. The increase of resistance to vancomycin observed in some of the studies already mentioned and also in a few European countries [31] is a matter of concern, but similar conclusions could not be drawn from the present study as most of the strains $(83.6 \%)$ were proven to be susceptible to this agent.

In overall, only $27.3 \%(21 / 77)$ of the isolates of this study were susceptible to all antibiotic agents (Table 3). About 23.4\% (18/77) were resistant to two antibiotics while multidrug resistance (to at least three agents) was observed for the $22.1 \%$ (17/77). Finally, isolates from only one milk sample showed to be resistant to all antibiotics.

\section{Conclusions}

Considering the elevated prevalence and overall resistance to antibiotics of Streptococcus spp. isolated from milk samples, further examinations and even interventions are required in the area in order to ensure both the animal health and the quality of the milk.

\section{Acknowledgments}

This research has been co-financed by the European Union (European Social Fund-ESF) and Greek National Funds through the Operational Program "Education and Lifelong Learning" of the National Strategic Reference Framework (NSRF)-Research Funding Program: THALES (\#OPS379408).

\section{References}

[1] Y.W. Park, M. Juárez, M. Ramos, G.F.W. Haenlein, Physico-chemical characteristics of goat and sheep milk, Small Ruminant Research 68 (2007) 88-113.

[2] A. Pappas, G. Kalantzopoulos, The History of Greek Dairy Industry, B2B Press Editions, Athens, Greece, 2007, p. 35 .

[3] E. Kondyli, C. Svarnas, J. Samelis, M.C. Katsiari, Chemical composition and microbiological quality of ewe and goat milk of native Greek breeds, Small Ruminant Research 103 (2012) 194-199.

[4] G. Marogna, S. Rolesu, S. Lollai, S. Tola, G. Leori, Clinical findings in sheep farms affected by recurrent bacterial mastitis, Small Ruminant Research 88 (2010) 119-125.

[5] A. Contreras, D. Sierra, J.C. Corrales, J.C. Marco, M.J. Paape, C. Gonzalo, Mastitis in small ruminants, Small Ruminat Research 68 (2007) 145-153.

[6] T.A. McAlister, L.J. Yanke, G.D. Inglis, M.E. Olson, Is antibiotic use in dairy cattle causing antibiotic resistance? Adv. Dairy Technology 13 (2001) 229-247.

[7] E. Bezirtzoglou, A. Alexopoulos, C. Voidarou, Apparent antibiotic misuse in environmental ecosystems and food, Microb. Ecol. Health Dis. 20 (2008) 197-198.

[8] X. Malher, H. Seegers, F. Beaudeau, Culling and mortality in large dairy goat herds managed under intensive conditions in Western France, Livestock Production Science 71 (2001) 75-86.

[9] G. Leitner, N. Silanikove, U. Merin, Estimate of milk and curd yield loss of sheep and goats with intrammamary infection and its relation to somatic cell count, Small Ruminant Research 74 (2008) 221-225.

[10] C.L. Little, J. de Louvois, Health risks associated with unpasteurized goats' and ewes' milk on retail sale in England and Wales: A PHLS Dairy Products Working Group study, Epidemiology and Infection 122 (1999) 403-408.

[11] D. Vassos, E. Bezirtzoglou, C. Voidarou, A. Alexopoulos, V. Maipa, Survey of probiotic enterococci from traditional dairy products and their impact upon the infant intestinal microbiota, J. Gen. Appl. Microbiol. 55 (2009) 311-315.

[12] L.P. Sorensen, T. Mark, M.K. Sorensen, S. Ostergaards, Economic vales and expected effect of selection index for pathogen specific mastitis under Danish conditions, J. Dairy Sci. 93 (2010) 358-369.

[13] M.A. Botrel, M. Haenni, E. Morignat, P. Sulpice, J.Y. Madec, D. Calavas, Distribution and antimicrobial resistance of clinical and subclinical mastitis pathogens in dairy cows in Rhône-Alpes, France, Foodborne Pathogens and Disease 7 (2010) 479-487.

[14] L.J. Teng, P.R. Hsueh, Y.C. Cheng, Antimicrobial 
susceptibility of viridians group streptococci in Taiwan with an emphasis on the high rates of resistance to penicillin and macrolides in Streptococcus oralis, J. Antimicrob. Chemother. 41 (1998) 621-627.

[15] A. Bryskier, Viridians group streptococci: A reservoir of resistant bacteria in oral cavities, Clin. Microbiol. Infect. 8 (2002) 65-69.

[16] P.V. Rossitto, L. Ruiz, Y. Kikuchi, K. Glenn, K. Luiz, J.L. Watts, et al., Antibiotic susceptibility patterns for environmental streptococci isolated from bovine mastitis in Central California dairies, Journal of Dairy Science 85 (2012) 132-138.

[17] H. Kaspar, Results of the antimicrobial agent susceptibility study raised in a representative, cross-sectional monitoring study on a national basis, International Journal of Medical Microbiology 296 (2006) 69-79.

[18] H.M. Nam, S.K. Lim, H.M. Kang, J.M. Kim, J.S. Moon, K.C. Jang, et al., Antimicrobial resistance of streptococci isolated from mastitic bovine milk samples in Korea, Journal of Veterinary Diagnostic Investigation 21 (2009) 698-701.

[19] S. Schwarz, W.C. Noble, Aspects of bacterial resistance to antimicrobials used in veterinary dermatological practice, Veterinary Dermatology 10 (1999) 163-176.

[20] J. El-Jakee, H.S. Hableel, M. Kandil, O.F. Hassan, E.A. Khairy, S.A. Marouf, Antibiotic resistance patterns of isolated from mastitic cows and ewes in Egypt, Global Veterinaria 10 (2013) 264-270.

[21] A. Ariznabarreta, C. Gonzalo, F.S. Primitivo, Microbiological quality and somativ cell count of ewe milk with special reference to staphylococci, J. Dairy Sci. 85 (2002) 1370-1375.

[22] H. Hariharan, W. Donachie, C. Macaldowie, G. Keefe, Bacteriology and somatic cell counts in milk samples from ewes on a Scottish farm, Canadian Journal of Veterinary Research 68 (2004) 188-192.

[23] J. Arsenault, P. Dubreuil, R. Higgins, D. Bélanger, Risk factors and impacts of clinical and subclinical mastitis in commercial meat-producing sheep flocks in Quebec, Canada, Preventive Veterinary Medicine 87 (2008) 373-393.

[24] C. Cuccuru, M. Meloni, E. Sala, L. Scaccabarozzi, C. Locatelli, P. Moroni, et al., Effects of intramammary infections on somatic cell score and milk yield in Sandra sheep, New Zealand Veterinary Journal 59 (2011) 128-131.

[25] E.M. Anifantakis, Bacteriological quality of raw goats milk in Greece, Lait 73 (1993) 465-472.

[26] I. Skoufos, C. Voidarou, E. Bezirtzoglou, A. Tzora, Effects of machine-milking on the bacterial flora of teat duct and mammary gland of ewes, Journal of Veterinary Medicine 53 (2006) 499-501.

[27] A. Alexopoulos, G. Tzatzimakis, E. Bezirtzoglou, S. Plessas, E. Stavropoulou, E. Sinapis, et al., Microbiological quality and related factors of sheep milk produced in farms of NE Greece, Anaerobe 17 (2011) 276-279.

[28] A. Ebrahimi, F. Nikookhah, S. Nikpour, F. Majiian, M. Gholami, Isolation of streptococci from milk samples of normal, acute and subclinical mastitis cows and determination of their antibiotic susceptibility patterns, Pakistan Journal of Biological Sciences: PJBS 11 (2008) 148-150.

[29] S.A. Lollai, M. Ziccheddu, C. Di Mauro, D. Manunta, A. Nudda, G. Leori, Profile and evolution of antimicrobial resistance of ovine mastitis pathogens (1995-2004), Small Ruminant Research 74 (2008) 249-254.

[30] H. Moatamedi, M.S. Shapouri, M. Ghorbanpoor, M. Jamshidian, S. Gooraninejad, A polymerase chain reaction based study on the subclinical mastitis caused by Streptococcus agalactiae, S. dysgalactiae and S. uberis in cattle in Ahvaz, Iranian J. Vet. Res. 8 (2007) 260-265.

[31] K. Minst, E. Märtlbauer, T. Miller, C. Meyer, Short communication: Streptococcus species isolated from mastitis milk samples in Germany and their resistance to antimicrobial agents, Journal of Dairy Science 95 (2012) 6957-6962. 